\title{
Beef Production on Lodgepole Pine-Pinegrass Range in the Cariboo Region of British Columbia ${ }^{1}$
}

\author{
ALASTAIR McLEAN \\ Range Ecologist, Canada Agriculture Research Station, \\ Kamloops, B. C.
}

\section{Highlight}

Results from the Cariboo grazing trail confirm those from previous ones on lodgepole pine-pinegrass summer range near Kamloops. They also suggest that similar results could be expected in other regions with ecologically similar sites. Yearling steers in the Cariboo district had a 3-year average daily gain of 1.74 lb. for 97 days starting in early June. The average gain per acre was $17.8 \mathrm{lb}$. The average carrying capacity was 4.6 acres/animal unit month.

Pinegrass (Calamagrostis rubescens) is generally considered to be unacceptable forage for cattle in the Cariboo region of British Columbia. Although McLean (1967) obtained satisfactory gains on yearling steers near Kamloops, popular belief was that these results would not apply farther north in the Cariboo. To obtain some knowledge on the response of beef cattle to grazing lodgepole pine-pinegrass forest range in the Cariboo district a trial was undertaken about 20 miles southeast of Williams Lake from 1968 through 1970.

The site is within the douglasfir zone at 3100 feet elevation. It is presently dominated by lodgepole pine, about 70 feet tall. A few old trees of douglasfir remain, however, and the reproduction is mostly douglasfir and lodgepole pine. Pinegrass dominates the ground cover. Twinflower (Linnaea borealis) is subdominant. Other species consistently present are rose (Rosa nutkana), ricegrass (Oryzopsis asperifolia), and creamy peavine (Lathyrus ochroleucus).

\section{Procedure}

Field A (81 acres) is typical of forest range in the district and had a moderately dense stand of lodgepole pine. Field B (72 acres) was logged about 10 years ago. Both fields have very similar ground

${ }^{1}$ Received $\Lambda$ pril 19, 1971. covers. The two fields were considered as replicates. Field C (161 acres) is covered by a dense stand of lodgepole pine and is discussed separately.

Yearling steers were turned in when the pinegrass was about 6 inches high and removed early in September before the weather turned stormy and the animals began to lose weight. The animals were on the fields for 104, 90, and 97 days in 1968, 1969, and 1970 respectively from early June to early September.

Adjustments in the number of animals per field were necessary as the forage became fully utilized. Therefore, average daily weight gains were based only on the animals that remained in the same field for the entire grazing period. Animals were generally weighed every 3 weeks.

In 1968 one-half of the animals were from the Kamloops Research Station while the rest were supplied by a local rancher. In 1969 all stock was provided by the Research Station. In 1970 all animals were bought in April in Williams Lake. All stock were grazed on open range prior to turnout.

\section{Results}

General observations in the fields indicated that cattle graze the pinegrass readily during June and July but tend to avoid it during the latter part of the summer. They did not especially avoid it while grazing under the trees but seemed to prefer to dally in the open areas. Observations on range adjacent to the fields suggested that the stock grazed only slightly where the trees formed a near-complete canopy when they had a choice.

The stocking rate for fields A and $B$ was 4.6 acres/animal unit month (AUM) (Table 1). The average gain per acre was $17.8 \mathrm{lb}$.

The average daily gain (ADG) was $1.74 \mathrm{lb}$. (Table 2). The ADG declined progressively, as the season advanced, from $2.61 \mathrm{lb}$. to $0.70 \mathrm{lb}$. The 1970 gains were $0.25 \mathrm{lb}$./day greater than for either of the other 2 years.

In 1968 the animals trucked from Kamloops needed 49 days to regain their leaving weight while the local ones needed only 3 days. The seasonal ADG for the Kamloops and local animals was 1.25 and $1.91 \mathrm{lb}$. respectively. The local animals, however, had a lower starting weight (457 vs $673 \mathrm{lb}$.) than those from Kamloops. In 1969, when all stock were trucked from Kamloops, they took 35 days to regain their leaving weight.

The animals were sold at the Williams Lake auction sales. They brought $\$ 25.50, \$ 32.00$, and $\$ 32.70$ per 100 lbs. in 1968, 1969, and 1970 respectively. The per-acre return was $\$ 3.95$, $\$ 5.12$, and $\$ 7.20$ for each of the 3 years.

The crude protein content of the pinegrass declined from turnout time onward as the grass matured (Table 3). The values for 1969 were lower throughout the season than either of the other 2 years. The crude protein trends were quite similar over the 3 years considering the very different weather patterns.

Field $\mathrm{C}$ was considered poor range because of the dense canopy of lodgepole pine. Pinegrass, however, was still the dominant groundcover species although the stand was thin in places. The object of grazing this field was to see if heavy shade had an adverse effect on the cattle. The carrying capacity was lower than expected so the animals 
Table 1. Production data for yearling steers on Cariboo experimental fields $A$ and $B$ from 1968 through 1970.

\begin{tabular}{lllccc}
\hline Year & $\begin{array}{c}\text { Start } \\
\text { date }\end{array}$ & $\begin{array}{c}\text { Finish } \\
\text { date }\end{array}$ & $\begin{array}{c}\text { Start } \\
\text { wt (lb.) }\end{array}$ & $\begin{array}{c}\text { Stock rate } \\
\text { (acre/AUM) }\end{array}$ & $\begin{array}{c}\text { Avg gain/ } \\
\text { acre (lb.) }\end{array}$ \\
\hline 1968 & June 6 & Sept 18 & 553 & 4.8 & 15.4 \\
1969 & June 5 & Sept 10 & 596 & 4.9 & 16.1 \\
1970 & June 4 & Sept 9 & 495 & 4.2 & 21.9 \\
Avg & June 5 & Sept 12 & 548 & 4.7 & 17.8 \\
\hline
\end{tabular}

had to be removed early each year. The stocking rates were 13,19 , and 24 acres/AUM for the 3 years. The average daily gains for the periods on the field were $1.96 \mathrm{lb}$. (63 days), 1.59 lb. (70 days), and $1.70 \mathrm{lb}$. (71 days).

Weather records were obtained at the site in 1970 only. Consequently the records for the Williams Lake airport, about 22 miles northwest, were used for year-toyear comparisons. The mean temperatures of the summer months (May through September) were 53, 56 , and $55 \mathrm{~F}$ for 1968,1969 , and 1970. The 5-month rainfall for 1968,1969 , and 1970 was $5.98,9.63$, and 3.83 inches respectively. The rainfall at the test fields in 1970 was 4.82 inches as compared with 3.83 inches at the airport.

\section{Discussion}

The concept of ecological sites is illustrated in the Cariboo grazing trails. That is, where results from one region can be applied to others provided they are ecologically similar. The results verify those obtained earlier in the Thompson Valley near Kamloops, about 120 miles southeast on similar range (McLean, 1967).

There are remarkable similarities in animal daily gains, gains per acre, and carrying capacities of the fields. The ground cover is similar in species and volume between the Cariboo and Kamloops sites. The chemical composition of the pinegrass is similar throughout the season. The ADG was 1.74 pounds in the Cariboo and 1.75 pounds at Kamloops. The Cariboo and Kamloops stocking rates were 4.6 and 4.8 acres per AUM respectively. The gains per acre were 17.8 and 19.3 pounds respectively.

The crude protein contents of the pinegrass were up to $2 \%$ lower in the Cariboo for comparative dates as compared with the Kamloops values (McLean et al., 1969). Some variation can be expected, however, because of difficulty in determining comparable growth stages since the grass does not always head out. Pinegrass dominates about $77 \%$ of the ground cover in the Cariboo fields and $80 \%$ at Kamloops. The site index for lodgepole pine is about 75 (per 100 years) at both locations.

The summer climates at the two locations are comparable. The Mayto-September mean temperature for 1970 was $54 \mathrm{~F}$ at the Cariboo fields

Table 2. Average daily gains (lb.) of yearling steers on Cariboo experimental fields by weigh periods from 1968 through 1970 .

\begin{tabular}{|c|c|c|c|c|c|c|c|}
\hline \multirow[b]{2}{*}{ Year } & \multicolumn{5}{|c|}{ Average weigh dates } & \multirow{2}{*}{$\begin{array}{l}\text { Season } \\
\text { A.D.G. }\end{array}$} & \multirow{2}{*}{$\begin{array}{l}\text { No. of } \\
\text { animals }\end{array}$} \\
\hline & June 5 & June 27 & Aug. 3 & Aug. 22 & Sept. 8 & & \\
\hline 1968 & 2.43 & 1.29 & 1.41 & 2.07 & 1.01 & 1.66 & 12 \\
\hline 1969 & 1.74 & 3.45 & 1.65 & 1.33 & 0.82 & 1.66 & 16 \\
\hline 1970 & 3.68 & 2.73 & 1.89 & 1.18 & 0.86 & 1.91 & 15 \\
\hline Avg & 2.61 & 2.48 & 1.64 & 1.52 & 0.89 & 1.74 & 14 \\
\hline
\end{tabular}

Table 3. Crude protein content (\%, oven dry wt) of pinegrass at various growth stages on the Cariboo experimental fields.

\begin{tabular}{lrrrr}
\hline \hline \multirow{2}{*}{$\begin{array}{c}\text { Average } \\
\text { date }\end{array}$} & \multicolumn{4}{c}{ Crude protein } \\
\cline { 2 - 4 } & 1968 & 1969 & 1970 & Average \\
\hline June 5 & 14.8 & 12.2 & 14.3 & 13.8 \\
June 27 & 11.9 & 10.2 & 9.6 & 10.6 \\
Aug. 3 & 8.1 & 7.5 & 9.0 & 8.2 \\
Aug. 22 & 7.5 & 5.6 & 6.8 & 6.6 \\
Sept. 8 & 6.5 & 4.2 & 5.2 & 5.3 \\
\hline
\end{tabular}

and $55 \mathrm{~F}$ at the Kamloops ones. The 1970 rainfall was 4.82 inches at the Cariboo fields and 5.13 inches at the Kamloops fields.

The results of the Cariboo trial suggest that pinegrass can be grazed successfully by yearling steers in that region during the summer, even under a tree canopy. Animals that were grazed on the field with the dense tree cover did not appear to suffer adverse effects since the daily gains were satisfactory. The main problem seemed to be the low carrying capacity. It appears necessary, however, to confine the animals on these areas to obtain full utilization.

The carrying capacities indicated for the test fields are higher than can be expected from larger range units since full utilization was obtained in the fields. No allowances had to be made for such factors as distance from water, accessibility, and topography; important factors on large range units.

\section{Literature Cited}

McLeAN, A. 1967. Beef production on a lodgepole pine-pinegrass range in southern British Columbia. J. Range Manage. 20:214-216.

Mclean, A., S. Freyman, J. E. MiltMORE, AND D. M. BowDEN. 1969. Evaluation of pinegrass as range forage. Can. J. Plant Sc. 49:351-359.

CLYDE ROBIN NATIVE SEEDS

Castro Valley, California 94546 